\title{
Effects of invertebrate pests on white and annual clovers in dryland soil
}

\author{
T.M. Eden, P.J. Gerard, D.J. Wilson and N.L. Bell \\ AgResearch, Private Bag 3123, Hamilton 3240 New Zealand \\ Corresponding author: tina.eden@agresearch.co.nz
}

\begin{abstract}
Two experiments were carried out at Ruakura in soil taken from Whatawhata hill country pasture. The relative susceptibility of several annual clovers (Trifolium spp.) and perennial white clover (T. repens) to slugs (Deroceras reticulatum), clover root weevil (Sitona lepidus) adults, native crickets (Nemobius sp.) or wheat bugs (Nysius huttoni) was tested by sowing seed of the clovers into separate rows in turf. Susceptibility of clovers to clover cyst nematode (Heterodera trifolii) was tested by sowing each clover variety into Whatawhata soil inoculated with the nematode. Plant growth was assessed in both experiments 4 weeks after sowing. White clover was more susceptible to pests than the annual clovers, with slugs and clover root weevil significantly reducing seedling survival, and clover cyst nematode significantly reducing plant growth. Subterranean clover (T. subterraneum) cv. Denmark was the least affected by pests, showing no significant reduction in survival in the presence of slugs, the most damaging pest, and no significant decrease in plant root and shoot dry weight when exposed to nematodes.
\end{abstract}

Keywords annual clover, pasture pests, nematodes, Heterodera trifolii, white clover, Trifolium, Nysius.

\section{INTRODUCTION}

Very little work has been carried out in New Zealand on the impact of invertebrate pests on the establishment of annual clovers in hill country (Rattray 2005). Many of the pests that attack white clover, such as slugs, crickets, nematodes and grass grub, can also attack and drastically reduce annual clover seedling survival (Rattray 2005). Some annual clovers are hosts of clover cyst nematode (Heterodera trifolii), which are extensively distributed in dry hill country of New Zealand (Mercer \& Woodfield 1986). When renewing pasture, use of a species or cultivar that is tolerant or resistant to these pests should therefore lift pasture performance. Due to the range and complexity of dryland farming systems, there is an opportunity and a need to widen the range of legumes used in these situations (Brown \& Green 2003). A better understanding of the impact invertebrates have on initial annual clover seedling establishment in hill country would help with clover selection and in assessing the cost-benefits of using control measures such as seed coatings.

This paper presents the results of experiments investigating impacts of selected pests on the emergence and early establishment of four annual clover species and white clover. 


\section{METHODS}

Experiments were run at the Ruakura Research Centre using hill country pasture turf collected from the Whatawhata Research farm (NZMS260 S14 935 750) in autumn 2009. Above-ground pests were collected from Whatawhata and Pyes Pa (NZMS260 U15 836 655) (Bay of Plenty), whereas Heterodera nematodes were sourced from a glasshouse colony at Ruakura.

\section{Above-ground pests}

Turves ( $5 \mathrm{~cm}$ deep) were cut to fit tightly into plastic troughs $(32 \times 15 \times 13 \mathrm{~cm}$ deep $)$ and the pasture cover trimmed close to the surface to simulate hard grazing. The turves were top-watered when required and kept well drained through drainage holes in the base of the troughs.

The experiment was a choice test with 10 seeds from each clover species (Table 1) sown into each trough, nine troughs sown per invertebrate pest and five troughs as controls containing no pests. Rows approximately $5 \mathrm{~mm}$ deep and $5 \mathrm{~cm}$ apart were cut across the width of each turf and each row was randomly allocated a clover species. However, as there were two subterranean clover cultivars and insufficient seed of either to be fully replicated, only the controls (five reps) and two or three replicates for each pest had both subterranean clovers present. The remaining replicates were randomly allocated one of the two subterranean cultivars to give a total of six replicates of Woogenellup and five of Denmark. Pasture pests were introduced once seedlings of all species had emerged and their cotyledons were open (ca 7 days).

Pest species were added to their respective troughs at the following rates: two clover root weevil (CRW) adults (Sitona lepidus, equivalent to $21 / \mathrm{m}^{2}$ ), two native crickets (Nemobius sp, $21 / \mathrm{m}^{2}$ ), four native wheat bugs (Nysius huttoni, $42 / \mathrm{m}^{2}$ ) and one grey field slug (Deroceras reticulatum, 10/ $\mathrm{m}^{2}$ ). Each trough was covered with plastic cling film with multiple holes pierced for aeration. This allowed containment and monitoring of invertebrate activity and feeding. The troughs were placed outdoors under shelter where they were exposed to natural temperatures and light, but protected from rain. A MiniTag digital temperature recorder was placed inside a spare covered trough where air temperature was recorded every 30 minutes.

The cling film and pests were removed after 1 week and seedling numbers assessed. The troughs were then moved to an unheated glasshouse and maintained for a further 3 weeks. Seedlings from each clover cultivar were then harvested at ground level, counted and green weight obtained. The existing background turf clover content was assessed by point analysis after harvest, recording the presence or absence of clover at 10 points at $2 \mathrm{~cm}$ spacing along the length of each turf.

The data were analysed using Residual Maximum Likelihood (REML) (Patterson \& Thompson 1971) in GenStat to produce means allowing for the unbalanced design arising from the two subterranean clover cultivars.

\section{Cyst nematodes}

Soil was crumbled from turves, sieved and mixed in a mechanical tumbler for $2 \mathrm{~min}$. Eighty root trainers $(35 \times 40 \times 110 \mathrm{~mm}$ deep $)$ were each filled with $130 \mathrm{~g}$ of soil and two of these were used to assess field nematode loadings using a variation

Table 1 The five clover (Trifolium) species and six cultivars tested.

\begin{tabular}{llll}
\hline Clover & Species & Cultivar/s & Seasonality \\
\hline Arrowleaf & T. vesiculosum & Apache & Annual \\
Balansa & T. michelianum & Balansa & Annual \\
Persian & T. resupinatum & Archibald & Annual \\
Subterranean & T. subterraneum & Denmark, Woogenellup & Annual \\
White & T. repens & Prestige & Perennial \\
\hline
\end{tabular}


of the Whitehead method (Bell \& Watson 2001). The remaining root trainers were frozen to $-20^{\circ} \mathrm{C}$ for 3 days to kill resident nematodes and a post-freezing soil sample was used to determine kill. Plant parasitic nematodes were identified to genera and total nematodes counted in a Doncaster dish at 50× magnification.

Once the soil had thawed, each root trainer received $1 \mathrm{ml}$ of either distilled water (- Nems) or nematode egg suspension (+ Nems) into a $2 \mathrm{~cm}$ deep hole in the centre of each trainer. The nematode egg suspension consisted of approximately 650 Heterodera trifolii eggs (approx. $412 \times 10^{3} / \mathrm{m}^{2}$ ) extracted from a culture maintained on white clover plants. The hole was partially filled then two clover seeds of Prestige, Apache, Balansa, Archibald or Denmark were sown ca $1 \mathrm{~cm}$ deep directly above the nematode inoculum in each trainer and thinned to a single plant after emergence. Each clover species $\times$ nematode treatment was replicated eight times. At sowing each trainer received $3 \mathrm{ml}$ tap water to encourage seed germination and ensure nematodes remained in moist soil. All trainers were moved to a $20^{\circ} \mathrm{C}$ controlled environment room with 16:8 h light:dark and watered daily.

Four weeks after sowing, the seedlings (shoot and roots) were removed from the trainers and washed free of soil. The number of trifoliate leaves present was determined, and the roots and shoots separated, oven dried and weighed.

All data were analysed using ANOVA in GenStat (Release 10.2). Tukeys LSD was used to check for significant differences.

\section{RESULTS}

\section{Above-ground pests}

The mean daily maximum temperature inside the troughs over the 4 week period from germination was $16^{\circ} \mathrm{C}$. Some re-growth of existing clover in the turves occurred prior to the addition of pests, but there was no significant difference in percent existing clover between the control troughs and pest treatments at the end of the trial period (overall clover cover was 18\%). Few seeds germinated after the first assessment so the Week 1 data are not presented. There was poor germination in Apache, Balansa and Archibald clovers with significantly fewer seedlings than other cultivars in control troughs at Week 1 (data not shown, $\mathrm{P}<0.001$ ) and Week $4(\mathrm{P}<0.001$, Table 2).

Slugs significantly reduced seedling survival in Archibald, Woogenellup and Prestige clovers $(\mathrm{P}<0.01$, Table 2), and approached significance in Apache $(\mathrm{P}=0.055)$. Although Denmark subterranean clover showed tolerance to all pests including slugs with no significant decrease in seedling numbers, all pest treatments significantly reduced Denmark seedling weights $(\mathrm{P}<0.001)$ compared to the controls (Table 3). Archibald and Woogenellup seedlings exposed to slugs had significantly lower mean seedling weights than the other pest and pest-free treatments (Table 3). CRW had a significant effect on Prestige seedling establishment (Table 2) with 21\% fewer seedlings surviving after exposure to this pest than in the controls $(\mathrm{P}<0.05)$. Over all cultivars, seedling weights were significantly lower in troughs containing Nysius, CRW and slugs compared to

Table 2 Number of seedlings present at Week 4, 3 weeks after pests had been removed.

\begin{tabular}{lccccccc}
\hline Cultivar & Control & Cricket & CRW & Nysius & Slug & Average & $\begin{array}{c}\text { LSD } \\
(\mathrm{P}=0.05)\end{array}$ \\
\hline Apache & 3.5 & 3.2 & 2.9 & 2.1 & 1.0 & 2.5 & 1.8 \\
Balansa & 2.0 & 1.3 & 1.1 & 2.0 & 0.6 & 1.4 & 1.3 \\
Archibald & 2.3 & 3.2 & 2.7 & 2.0 & 0.6 & 2.2 & 1.5 \\
Denmark & 8.6 & 8.0 & 8.4 & 8.2 & 7.4 & 8.0 & 1.6 \\
Woogenellup & 9.5 & 8.3 & 8.7 & 9.0 & 4.8 & 8.2 & 1.7 \\
Prestige & 8.7 & 7.4 & 6.9 & 8.1 & 3.8 & 7.0 & 1.7 \\
\hline LSD $(\mathrm{P}=0.05)$ & 1.8 & 1.3 & 1.7 & 1.5 & 1.2 & 0.7 & \\
\hline
\end{tabular}


the pest-free controls $(\mathrm{P}<0.001$, Table 3$)$. Nysius huttoni had its greatest effect on the subterranean clovers, causing a significant reduction in shoot weight of both Denmark and Woogenellup.

\section{Cyst nematodes}

Prior to soil freezing, five genera of plant feeding nematodes were identified. Root-knot (Meloidogyne) and cyst (Heterodera) nematode densities were each 10/100 g soil, whereas lesion (Pratylenchus), pin (Paratylenchus) and spiral (Helicotylenchus) densities were 65, 15 and 5/100 $\mathrm{g}$ soil respectively. No plant feeding nematodes were observed post-freezing.

Significantly fewer Balansa, Apache and Archibald clover seedlings germinated over the 4-week trial period compared to Prestige and Denmark $(\mathrm{P}<0.001$, Table 4). Denmark had significantly more trifoliate leaves (3.3) at the end of the trial period than all other clovers (2.0, 2.1, 1.3 and 1.0 for Apache, Balansa, Archibald and Prestige, $\mathrm{P}<0.001$, LSD $(\mathrm{P}=0.05)=0.4)$ regardless of nematode treatment. Archibald and Prestige had significantly fewer trifoliate leaves than all other clovers at harvest.

White clover shoot and root dry matter was significantly reduced in the presence of cyst nematodes $(\mathrm{P}<0.05$, Table 4$)$. Apache clover, however, had greater average shoot and root dry matter when inoculated with nematodes with this difference being significant for root weights. No other clover species were significantly affected by nematodes.

\section{DISCUSSION}

While both subterranean clover cultivars and Prestige clover had good germination, Apache, Balansa and Archibald clovers had poor

Table 3 Mean wet shoot weight (mg) of surviving seedlings at Week 4.

\begin{tabular}{lrrrrrrc}
\hline & Control & Cricket & CRW & Nysius & Slug & Average & $\begin{array}{c}\text { LSD } \\
(\mathrm{P}=0.05)\end{array}$ \\
\hline Apache & 13.2 & 13.3 & 13.4 & 11.2 & 4.2 & 11.0 & 8.8 \\
Balansa & 4.4 & 5.4 & 3.6 & 5.0 & 3.1 & 4.3 & 4.8 \\
Archibald & 12.3 & 13.7 & 12.0 & 11.2 & 1.8 & 10.3 & 7.9 \\
Denmark & 99.1 & 80.2 & 71.8 & 74.5 & 60.7 & 77.8 & 15.7 \\
Woogenellup & 87.2 & 73.4 & 76.4 & 66.4 & 37.9 & 68.1 & 17.9 \\
Prestige & 4.6 & 4.1 & 4.2 & 4.3 & 2.9 & 4.0 & 1.4 \\
\hline Average & 36.8 & 31.7 & 29.9 & 29.6 & 18.4 & & 4.8 \\
LSD (P=0.05) & 8.7 & 9.2 & 7.7 & 10.6 & 5.1 & 4.0 & \\
\hline
\end{tabular}

Table 4 Percent germination and mean individual shoot and root dry weight for each clover species with (+Nems) or without (-Nems) nematodes.

\begin{tabular}{|c|c|c|c|c|c|c|c|}
\hline \multirow[b]{2}{*}{ Clover cultivar } & \multicolumn{3}{|c|}{ Shoot weight (mg) } & \multicolumn{3}{|c|}{ Root weight (mg) } & \multirow[b]{2}{*}{$\begin{array}{c}\% \\
\text { germination }\end{array}$} \\
\hline & $-\mathrm{Nems}$ & $+\mathrm{Nems}$ & $\begin{array}{c}\text { LSD } \\
(\mathrm{P}=0.05)\end{array}$ & -Nems & $+\mathrm{Nems}$ & $\begin{array}{c}\text { LSD } \\
(\mathrm{P}=0.05)\end{array}$ & \\
\hline Apache & 12.1 & 15.2 & 4.0 & 6.3 & 10.5 & 3.7 & 53 \\
\hline Balansa & 5.3 & 5.4 & 4.5 & 2.9 & 2.6 & 2.7 & 25 \\
\hline Archibald & 7.9 & 7.6 & 1.9 & 6.6 & 5.5 & 2.5 & 41 \\
\hline Denmark & 41.5 & 43.3 & 8.1 & 30.0 & 34.0 & 8.2 & 91 \\
\hline Prestige & 5.3 & 3.7 & 1.5 & 3.8 & 2.3 & 1.2 & 85 \\
\hline $\operatorname{LSD}(\mathrm{P}=0.05)$ & & & & & & & 22 \\
\hline
\end{tabular}


germination in both the turf and nematode assays. Clovers have a facility to produce hard seed, which allows the population to survive "false strikes" during erratic summer rainfall (Smetham 2003) whereby a proportion of the seed may germinate and die. Insufficient presowing scarification (physical scouring to break hard seed coat) or the age of the seed (accession dates 1993) may have affected germination in these experiments.

Little is known of the impact of invertebrate pests on annual clover establishment, therefore the levels of pests used were based on what would be typical for hill country/dryland populations. Ferguson \& Barratt (1983) found that slug densities of 5 and 10 slugs $/ \mathrm{m}^{2}$ could significantly reduce white clover seedling establishment following direct drilling into sprayed pasture. Barker et al. (1983) found clover to be the preferred diet of slugs over grasses so that in the trough experiment although slugs had the choice of existing pasture as well as newly-germinated clover seedlings, it is likely the clover seedlings were targeted by slugs. For clover root weevil it has been found that autumn adult populations in hill country near Bulls in the Manawatu peak at $20 / \mathrm{m}^{2}$ (Gerard et al. 2007), similar to the $21 / \mathrm{m}^{2}$ used in the current study. The nematode inoculum level $\left(412 \times 10^{3} / \mathrm{m}^{2}\right)$ was comparable to levels found in Rukuhia pasture $\left(731 \times 10^{3} / \mathrm{m}^{2}\right)$ in the Waikato (Yeates et al. 1983). This is a medium to high nematode population (N.L. Bell, AgResearch, unpublished data).

Slugs were the most damaging pest in these experiments, causing significant seedling losses in four cultivars. Although the effect on Balansa was not statistically significant, seedling numbers were reduced by greater than 50\%. Charlton (1978) considered slugs a factor in poor hill country clover establishment in the 1970s and subsequently found that subterranean clover was affected less than white clover and red clover (T. pratense) (Charlton 1979). Denmark subterranean clover seedling survival was not affected by any of the pests, including slugs, but plant growth was checked by all pests in the above-ground experiment.
White clover was the most vulnerable of the species tested in this experiment, with significant loss of seedlings by slugs and clover root weevil. Seedling survival of all annual clovers tested was not significantly affected by CRW. Dryland pastures with established annual clovers are relatively tolerant to CRW larval damage, and CRW populations are severely limited by summer drought (Crush et al. 2008), so it is likely that CRW is not a problem for establishment of these clovers in dryland sites.

White clover root and shoot weights were also significantly reduced when exposed to the clover cyst nematode $H$. trifolii, as shown previously by Yeates et al. (1973). Their work found subterranean clovers to be tolerant nonhosts to $H$. trifolii, meaning the clovers are invaded by nematodes but there is no significant nematode reproduction or host reaction. Further work by Yeates (1974) showed H. trifolii to have no significant effect on subterranean clover production. In the current study, Denmark (and indeed all annual clovers tested) showed no negative response to the presence of $H$. trifolii, which suggests they are indeed tolerant to this pest. The tolerance of these clovers to clover cyst nematode could be further studied to determine their potential as a "trap crop" to benefit white clover establishment. Some evidence exists to support this idea. Watson et al. (2000) observed fewer cyst nematodes in white clover roots grown in association with partially cyst-resistant Caucasian clover (T. ambiguum) than in roots of white clover grown alone. In hill country areas where cyst nematodes are likely to be the predominant plant parasitic nematode (Mercer \& Woodfield 1986) any resistance or tolerance to these nematodes would be an advantage.

Apache had a significant increase in seedling root and shoot growth after cyst nematode inoculation, indicating that this clover can not only tolerate but perhaps benefit from cyst nematode infestation. Small populations of plant parasitic nematodes in roots can result in increased plant growth (Yeates et al. 1999), so it is possible that the cyst nematodes induced the increased growth in Apache. 
These two experiments have shown that the annual clover cultivars tested were not susceptible to clover cyst nematode, and whilst susceptible to damage by slugs, there was some variation between subterranean clover cultivars. This variation in tolerance/resistance could be exploited to gain better autumn establishment and subsequent persistence, increasing the contribution these clovers make to pasture quality particularly in spring when forage demands of dryland animals are greatest.

\section{ACKNOWLEDGEMENTS}

This project was funded by Meat \& Wool New Zealand.

\section{REFERENCES}

Bell NL, Watson RN 2001. Optimising the Whitehead and Hemming tray method to extract plant parasitic and other nematodes from two soils under pasture. Nematology 3: 179-185.

Barker GM, Willoughby BE, Pottinger RP 1983. Feeding by slugs on some pasture plant species: laboratory experiments. Proceedings of the 36th New Zealand Weed and Pest Control Conference: 207-211.

Brown CD, Green RB 2003. The challenges facing legumes in a dryland environment - a consultant's view. In Moot DJ ed. Legumes for dryland pastures. Grassland Research and Practice Series 11, New Zealand Grasslands Association, Wellington. Pp. 7-12.

Charlton JFL 1978. Control of slug damage in oversown pasture legumes. Proceedings of the 31st New Zealand Weed and Pest Control Conference: $127-130$

Charlton JFL 1979. Effects of slugs during establishment of oversown legumes in box experiments. Proceedings of the 2 nd Australasian Conference on Grassland Invertebrate Ecology: 253-255.

Crush JR, Gerard PJ, Ouyang L, Wilson DJ 2008. Effect of clover root weevil and moisture stress on subterranean, balansa, Persian, arrowleaf and white clovers. Proceedings of the New Zealand Grassland Association 70: 255-257.
Ferguson CM, Barratt BIP 1983. Slug damage to pasture renovated by direct drilling. Proceedings of the 36th New Zealand Weed and Pest Control Conference: 212-215.

Gerard PJ, Eden TM, Hardwick S, Mercer CF, Slay MWA, Wilson DJ 2007. Initial establishment of the Irish strain of Microctonus aethiopoides in New Zealand. New Zealand Plant Protection 60: 203-208.

Mercer CF, Woodfield DR 1986. A survey of root knot and clover cyst nematodes in dry hill country. Proceedings of the New Zealand Grassland Association 47: 267-271.

Patterson HD, Thompson R 1971. Recovery of inter-block information when block sizes are unequal. Biometrika 58 (3): 545-554.

Rattray PV 2005. Clover management, research, development and extension in the New Zealand pastoral industries. A review of R\&D literature and R\&D opportunities, extension initiatives and extension opportunities. Sustainable Farming Fund Report [ISBN 0-478-29827-7]. $218 \mathrm{p}$.

Smetham ML 2003. A review of subterranean clover (Trifolium subterraneum L.): its ecology, and use as a pasture legume in Australasia. Advances in Agronomy 79: 303-350.

Watson RN, Bell NL, Neville FJ, Davis LT 2000. Pest populations during the first six years in ryegrass pastures containing white or Caucasian clover. New Zealand Plant Protection 53: 410-414.

Yeates GW, Healy WB, Widdowson JP 1973. Screening of legume varieties for resistance to the root nematodes Heterodera trifolii and Meloidogyne hapla. New Zealand Journal of Agricultural Research 16 (1): 81-86.

Yeates GW 1974. Effects of Heterodera trifolii on the growth of clover in a yellow-grey earth under greenhouse conditions. New Zealand Journal of Agricultural Research 17: 379-85.

Yeates GW, Stannard RE, Barker GM 1983. Vertical distribution of nematode populations in Horotiu soils. New Zealand Soil Bureau Scientific Report 60: 14.

Yeates GW, Saggar S, Hedley CB, Mercer CF 1999. Increase in ${ }^{14} \mathrm{C}$-carbon translocation to the soil microbial biomass when five species of plantparasitic nematodes infect root of white clover. Nematology 1 (3): 295-300. 